\title{
Characteristics of cassava starch fermentation wastewater based on structural degradation of starch granules
}

\author{
Características das águas residuais da fermentação do amido de \\ mandioca com base na degradação estrutural dos grânulos de amido
}

\begin{abstract}
Juliane Mascarenhas Pereira ${ }^{I}$ Ana Carolina Moura de Sena Aquino ${ }^{I}$ Daiana Cardoso de Oliveira ${ }^{I I}$ Gabriela Rocha ${ }^{I}$ Alícia de Francisco ${ }^{I}$ Pedro Luiz Manique Barreto ${ }^{I}$ Edna Regina Amante $^{I^{*}}$
\end{abstract}

\begin{abstract}
Sour cassava starch is a naturally modified starch produced by fermentation and sun drying, achieving the property of expansion upon baking. Sour cassava starch'bakery products can be prepared without the addition of yeast and it is gluten free. The fermentation process associated with this product has been well studied, but the wastewater, with high acidity and richness in other organic compounds derived from starch degradation, requires further investigation. In this study, the structure of solids present in this residue was studied, seeking to future applications for new materials. The solids of the wastewater were spray dried with maltodextrin (MD) with dextrose equivalent (DE) of 5 and 15 and the structure of the powder was evaluated by scanning electron microscopy. A regular structure with a network arrangement was observed for the dried material with MD of 5 $D E$, in contrast to the original and fermented starches structure, which suggests a regular organization of this new material, to be studied in future applications.
\end{abstract}

Key words: sour cassava starch, fermentation, water, microstructure.

\section{RESUMO}

O polvilho azedo é um amido naturalmente modificado, produzido por fermentação e seco ao sol, atingindo a propriedade de expansão. Produtos de panificação a partir do polvilho azedo podem ser preparados sem a adição de leveduras e são livres de glúten. O processo fermentativo tem sido exaustivamente estudado, mas as águas residuais com elevada acidez e ricas em compostos orgânicos derivados da degradação do amido, requerem futuros trabalhos. Neste estudo, a estrutura dos sólidos presentes nesse efluente foi estudada vislumbrando futuras aplicações para estes novos materiais. Os sólidos contidos na água residual foram secos em spray dryer com maltodextrina
(MD), com equivalente de dextrose (DE) de 5 e 15. A estrutura das partículas foi observada por microscopia eletrônica de varredura. Uma estrutura regular com arranjo em rede foi observada para o material seco com MD DE 5, em características que diferem das estruturas do amido nativo e do amido fermentado, o que sugere uma nova e regular organização estrutural com futuras aplicações a serem determinadas.

Palavras-chave: amido de mandioca, fermentação, águas, microestrutura.

\section{INTRODUCTION}

Studies about the chemical composition of residues could be a good way to change the preconception about how they can offer opportunities for the creation of a new raw material. Food industry produces a big quantity of wastewaters some of which have not been studied yet. Sour cassava starch' wastewater can be a good example of this.

Sour cassava starch (polvilho azedo) is a well-known product in Brazil and in other Latin America countries including Argentina, Colombia and Ecuador. In comparison to native cassava starch it presents significant differences in $\mathrm{pH}$, acidity, viscosity, density and other physicochemical properties. An exceptional and the most important property of this product is its expansion. MARCON et al. (2009) proposed a chemical explanation for the

ICentro de Ciências Agrárias (CCA), Departamento de Ciência e Tecnologia de Alimentos, Universidade Federal de Santa Catarina (UFSC), Rodovia Admar Gonzaga, 1346, Itacorubi, 88034-001, Florianópolis, SC, Brasil. E-mail: eamante@cca.ufsc.br. "Corresponding author.

IIDepartamento de Engenharia Química e de Alimentos, Centro Tecnológico, Universidade Federal de Santa Catarina (UFSC), Florianópolis, SC, Brasil. 
expansion of sour cassava starch, i.e., that results from polysaccharide degradation, generation of acids, dextrin and oxidized products during the fermentative process and sun drying.

The sour cassava starch production begins with the extraction of starch, which consists of cleaning, peeling, chopping, pressing and straining the cassava roots. Fibber is firstly separated from the starchy water and then the starch is separated from the water by decantation or centrifugation according to the plant scale. Cassava starch is then dried or submitted to natural fermentation to produce sour cassava starch. This fermentation process is carried out empirically, based only on the practical knowledge of the producer. It is a submerged fermentation process, with a superficial layer of $20 \mathrm{~cm}$ of water and involves very long time periods. The fermentative process starts with the production of sugar by microorganisms that hydrolyze the starch, a step which can be accelerated by the addition of glucose (MARCON et al., 2006).

The microorganisms typically associated with cassava starch fermentation are mainly lactic acid bacteria with a predominance of the genus Lactobacillus (L. plantarum, L. fermentum, L. delbrueckii and L. manihotvorans), followed by Streptococcus, Enterococcus, Leuconostoc, Pediococcus and Lactococcus (MORLON-GUYOT et al., 1998). These microorganisms are known to be responsible for the production of organic acids and aromatic compounds. Lactobacillus plantarum is known to produce antimicrobial substances (plantaricin) that are active against certain pathogens and a variety of strains are marketed as probiotics (De VRIES et al., 2006).

Currently, the wastewater from the fermentation process is discarded and it is considered an effluent with high chemical and biochemical oxygen demand (COD and BOD, respectively). However, this residue presents an interesting composition for potential use in new products, such as probiotic beverages, or in other applications.

During the cassava starch fermentative process, the starch granules are submerged in the fermentation tanks, as shown in figure 1. These tanks are around 10 to $20 \mathrm{~m}^{3}$ and starch represents the bulk of the mass: for each ton of sour cassava starch, around 120L of wastewater are obtained. Wastewater from this process has been studied by AVANCINI et al. (2007) and new studies are underway to identify the compounds present as soluble and suspended solids in this fermentation water (AVANCINI et al., 2007).
It can be assumed that this wastewater is comprised of acids, such as acetic, butyric, propionic, butyric and lactic acids, and the products of amylose and amylopectin degradation, such as dextrin, oligosaccharides and monosaccharides (data non published).

MARCON et al. (2006) and several other researchers (ASCHERI \& VILELA, 1995; PLATAOVIEDO \& CAMARGO, 1995; MESTRES \& ROUAU, 1997; DEMIATE et al., 2000; MESTRES et al., 2000) investigated the effect of fermentation on the cassava starch granule during processing and showed that the cassava starch granule presented perforations as a consequence of the microbiological degradation of this polysaccharide.

Studies on the structure of the solids present in the wastewater of the cassava starch fermentation process appear to be lacking in the literature. Scanning electronic microscopy can provide an insight into the effects of this fermentation processing on the microstructure of the remaining starch granules. The aim of this study was to assess the chemical composition of the soluble and suspended solids present in sour cassava starch' processing wastewater, based on changes in the cassava starch granule structure.

\section{MATERIALS AND METHODS}

Materials

Cassava starch fermentation wastewater was collected from three producer regions in the state of Santa Catarina, Brazil (São João do Sul - P1, Ibirama P2 and Agronômica - P3). Due to the low total solids content was adjusted with maltodextrin DE (Dextrose Equivalent) 5 and 15 (Lorenz Co., Quatro Pontes, Paraná, Brazil) in a proportion of $100 \%$ of the total solids present in the wastewater samples (proportionally to the total solids of the wastewater, 1:1, solid/solid).

The solutions were atomized in a Mini Spray Dryer B-290 (BÜCHI) using the following parameters: inlet temperature $130^{\circ} \mathrm{C}$, with a gas flow rate of $35 \mathrm{~m}^{3}$ $\mathrm{h}^{-1}$ and a feed flow of $10 \mathrm{~mL} \mathrm{~min}{ }^{-1}$. Dried material was packed in a polyethylene bag as primary package and a rigid plastic (PVC) container as secondary package, providing a total barrier to moisture, and stored at ambient temperature until analysis. A commercial sample of native cassava starch was also compared to the spray dried materials for electron microscopy.

Methods

Scanning electron microscopy

The material produced from the drying of the cassava starch fermentation wastewater, the native 


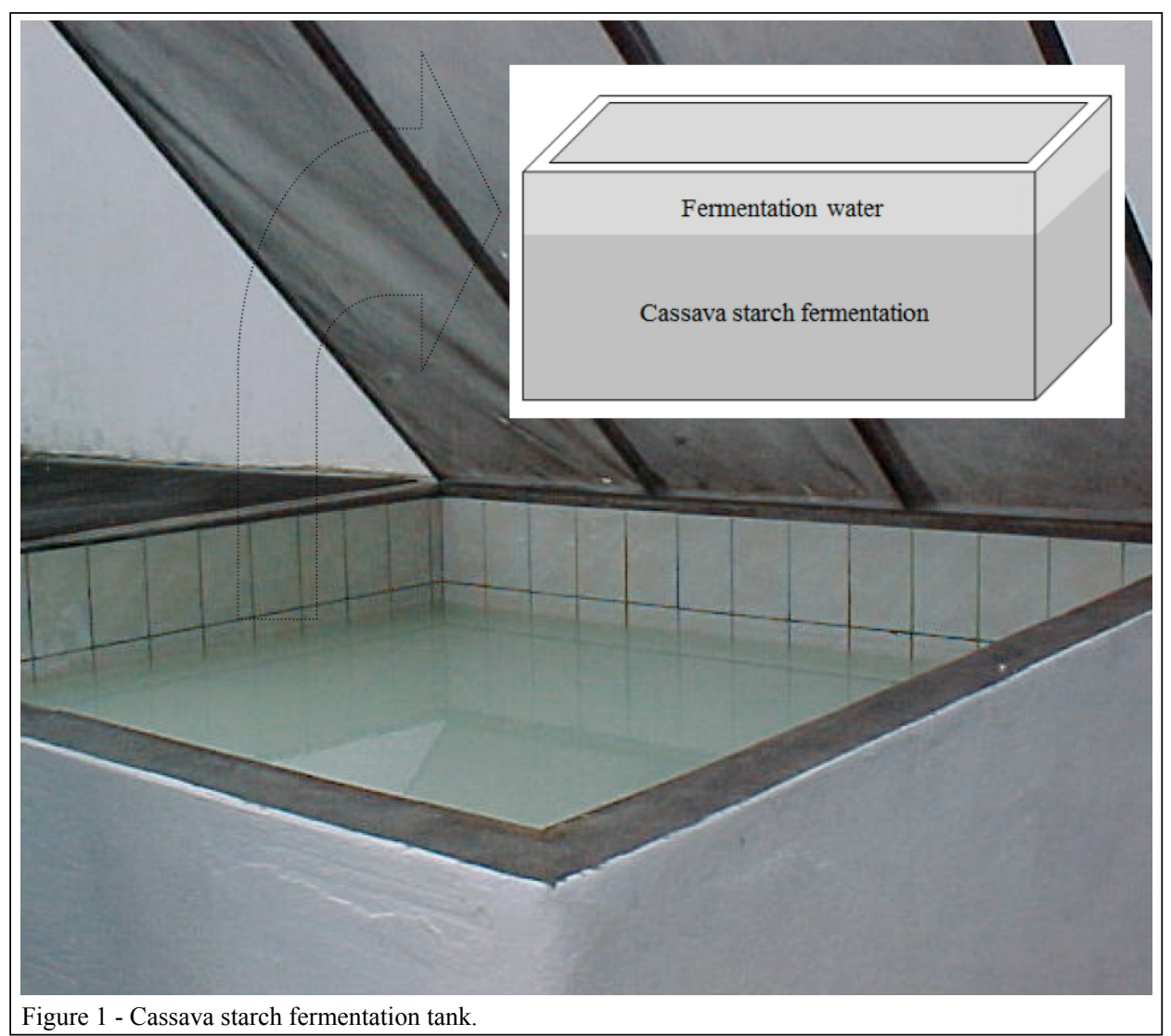

starch and the maltodextrins used, were analyzed by scanning electron microscopy. The dried samples were fixed on an aluminium stubs with double-sticky carbon tape, coated with gold $(350 \AA$ thick) using a sputtering system, model D2 Diode (International Scientific Instruments) and subjected to SEM analysis on a Jeol JSM-6390LV microscope.

\section{Physicochemical properties}

The $\mathrm{pH}$ of the fermentation water was determined using a Quimis $\mathrm{pH}$ meter, model Q 400 A (Diadema, São Paulo, Brazil) and titratable acidity was determined with $0.1 \mathrm{~mol} \mathrm{~L}^{-1} \mathrm{NaOH}$ solution. Total solids content was determined by drying $10 \mathrm{~mL}$ of the water in a forced-air oven until constant weight. All analyses were carried out in triplicate.

\section{Statistical analysis}

The results for the $\mathrm{pH}$, acidity and total solids content of the cassava starch fermentation wastewater were expressed as average and standard deviation. Differences between averages where compared by applying the Tukey test at $5 \%$ of significance.

\section{RESULTS AND DISCUSSION}

Cassava starch granules generally have similar characteristics, but they can present some differences according to the harvesting conditions and time of harvesting, resulting in several granule sizes which can lead to different enzymatic susceptibility during fermentation. Small, medium and large granules can be hydrolyzed differently, which can also result in different characteristics in the soluble and suspended solids in the fermentation water. Additionally, because of artisanal production of most industries of sour cassava starch, fermentation, conditions such as temperature, microorganisms and others were not controlled.

Table 1 shows the $\mathrm{pH}$, total solids and titratable acidity of the fermentation wastewater obtained from three different producer regions in Santa Catarina, Brazil. In addition to the above differences between samples, the type of microorganisms was also specific to the different regions of production, and this can contribute to large variations in some parameters, particularly the titratable acidity, which is related to the specific $\mathrm{pKa}$ values of several organic acids generated during the cassava starch fermentation. 
Table 1 - The acidity, $\mathrm{pH}$ and total solids of the cassava starch fermentation wastewater obtained from three producer regions in Santa Catarina State.

\begin{tabular}{lccc}
\hline Sample & $\mathrm{pH}$ & $\begin{array}{c}\text { Titratable acidity (mL of 0.1 } \\
\text { mol L }\end{array}$ & $\begin{array}{c}\text { Total solids } \\
\left(\mathrm{g} 100 \mathrm{~mL}^{-1}\right)\end{array}$ \\
\hline P1 & $3.40 \pm 0.00^{\mathrm{c}}$ & $15.02 \pm 0.00^{\mathrm{a}}$ & $0.17 \pm 0.01^{\mathrm{a}}$ \\
P2 & $3.50 \pm 0.01^{\mathrm{b}}$ & $9.50 \pm 0.06^{\mathrm{b}}$ & $0.15 \pm 0.00^{\mathrm{b}}$ \\
P3 & $3.61 \pm 0.01^{\mathrm{a}}$ & $9.69 \pm 0.05^{\mathrm{b}}$ & $0.17 \pm 0.01^{\mathrm{b}}$ \\
\hline
\end{tabular}

*Lowercase letters compare averages, in the same column. For different letters values differ significantly $(\mathrm{P}<0.05)$ according to the Tukey's test.

P1 - São João do Sul; P2 - Ibirama; P3 - Agronômica.

The average of the titrable acidity was $11.40 \mathrm{~mL} \mathrm{NaOH} 0.1 \mathrm{~N} 10 \mathrm{~mL}^{-1}$ of the wastewater. According to DEMIATE et al. (2000), propionic, butyric, acetic and lactic acids are present in sour cassava starch. Each tank produces around 120L of this effluent, which means the possibility of producing $480 \mathrm{~g}$ of organic acids per fermentation tank. Considering that this production is a residual material of the cassava starch fermentation, beside the characterization of the structures, the composition and valorization of this new material should be studied for future application where the property of these acids are required. The total solids in the cassava starch fermentation wastewater are probably comprised of hydrolyzed amylose and amylopectin molecules, besides organic acids and residual microorganism cells. AQUINO et al. (2015), showed that sour cassava starch wastewater can be an important source of organic acids.

In this study, the fermentation water was dried in a spray drier, with maltodextrin, of different grades of DE (5 and 15), added to decrease the energy consumption, minimize the effect of the acid on the spray drier structure and as well as to increase the yield of the dried product and its storage time for future use.

The microstructure of spray dried native cassava starch granules, fermentation damaged granules and total solids in the fermentation wastewater can be observed in figures 2 and 3. Figure 3, refers to the wastewater plus maltodextrin (DE 5 and 15), The effect of two kinds of maltodextrins on the
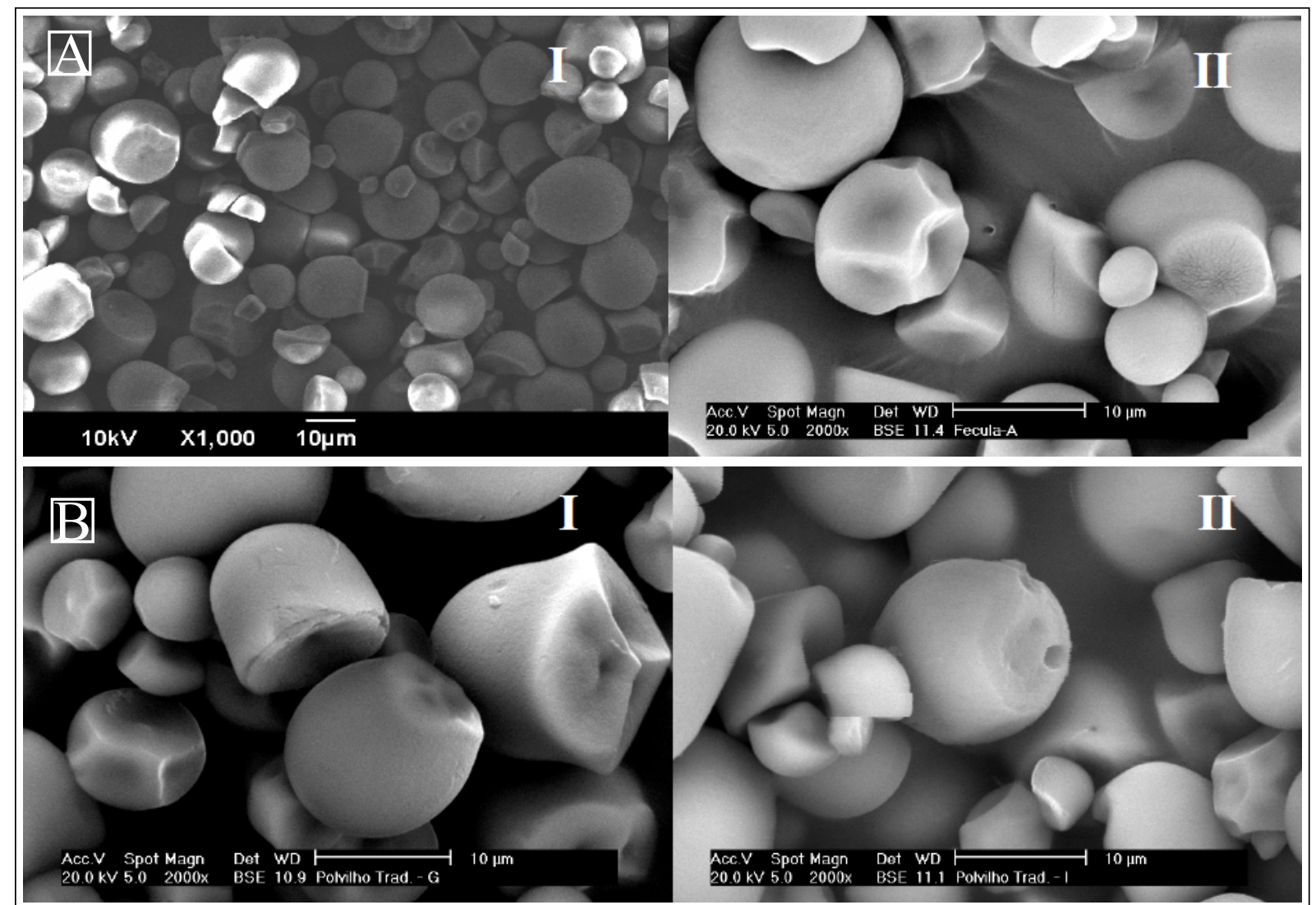

Figure 2 - Scanning electron micrography of a native cassava starch granule (A): I - 1000X e II - 2000X and sour cassava starch granule (B): I and II - 2000X.

Ciência Rural, v.46, n.4, abr, 2016. 


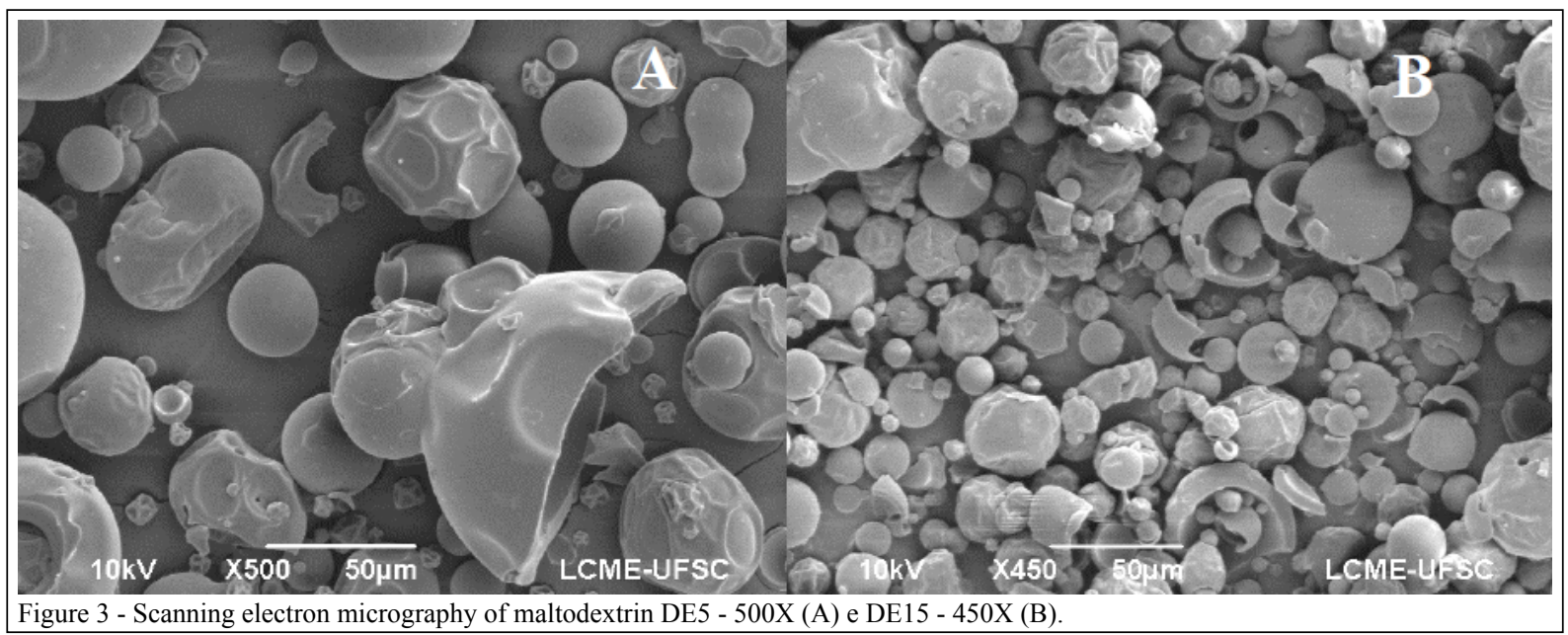

structure of sour cassava wastewater P1, P2 and $\mathrm{P} 3$ from three different industries showed differences between maltodextin according to their origin. A more regular structure, with a network covering the maltodextrin particles was observed in the dried samples with maltodextrin DE 5, which probably could result in a more stable particle upon storage.

Cassava starch granules were homogeneous and did not present any holes in their native form (Figure 2A). Conversely, fermented cassava starch granules (Figure 2B), showed perforations produced by enzymes that use the starch as a substrate for sugar production, particularly during the first step of the process. The soluble and insoluble solids content of the fermentation wastewater showed fermentative degradation of the granules, as well as some material resulting from microorganisms growth during the processing.

The maltodextrin, used as a material to improve the total solids content for the spray drying process (Figure 4), presented broken structures, but of a different nature compared to the native and sour cassava starch granules. Thus, the structures presented in figure 3, although being the residual solids from the cassava starch fermentation, showed different structural characteristics from the native starch, sour cassava starch and pure maltodextrin (used as a support during the drying process).

MARCON et al. (2009) showed that the sour cassava starch expansion property was due to the compounds of a molecular mass smaller than amylose and amylopectin, that formed an arrangement that supported water and gases retention during baking. However, cassava starch fermentation wastewater, beside lactic, propionic, butyric and acetic acids, most likely contains oligomeric and polymeric compounds. This merits further study since these compounds could be of value in the development of new materials from an industrial effluent, changing what is considered as polluting charge in a probable new raw material.

\section{CONCLUSION}

From green chemistry's stand point, the knowledge of residues composition, can contribute to future applications and reduction of pollution charge. This is problaby the first research showing the microscopic characteristics of the cassava starch fermentation solids wastewater. The structure of the solids presented in cassava starch fermentation wastewater dried by spray drying with maltodextrin DE 5 and 15 showed a regular network arrangement.

The microstructural arrangement of this material is different of the native and fermented cassava starch as well from the pure maltodextrin, and thus structurally characteristic of this new material produced from wastewater of the cassava starch fermentation process.

In the same manner that the sour cassava starch has special properties, the effluent of the cassava starch fermentation process can be consider for future researches as a new potential material such as active biofilms, as example of possible application. 


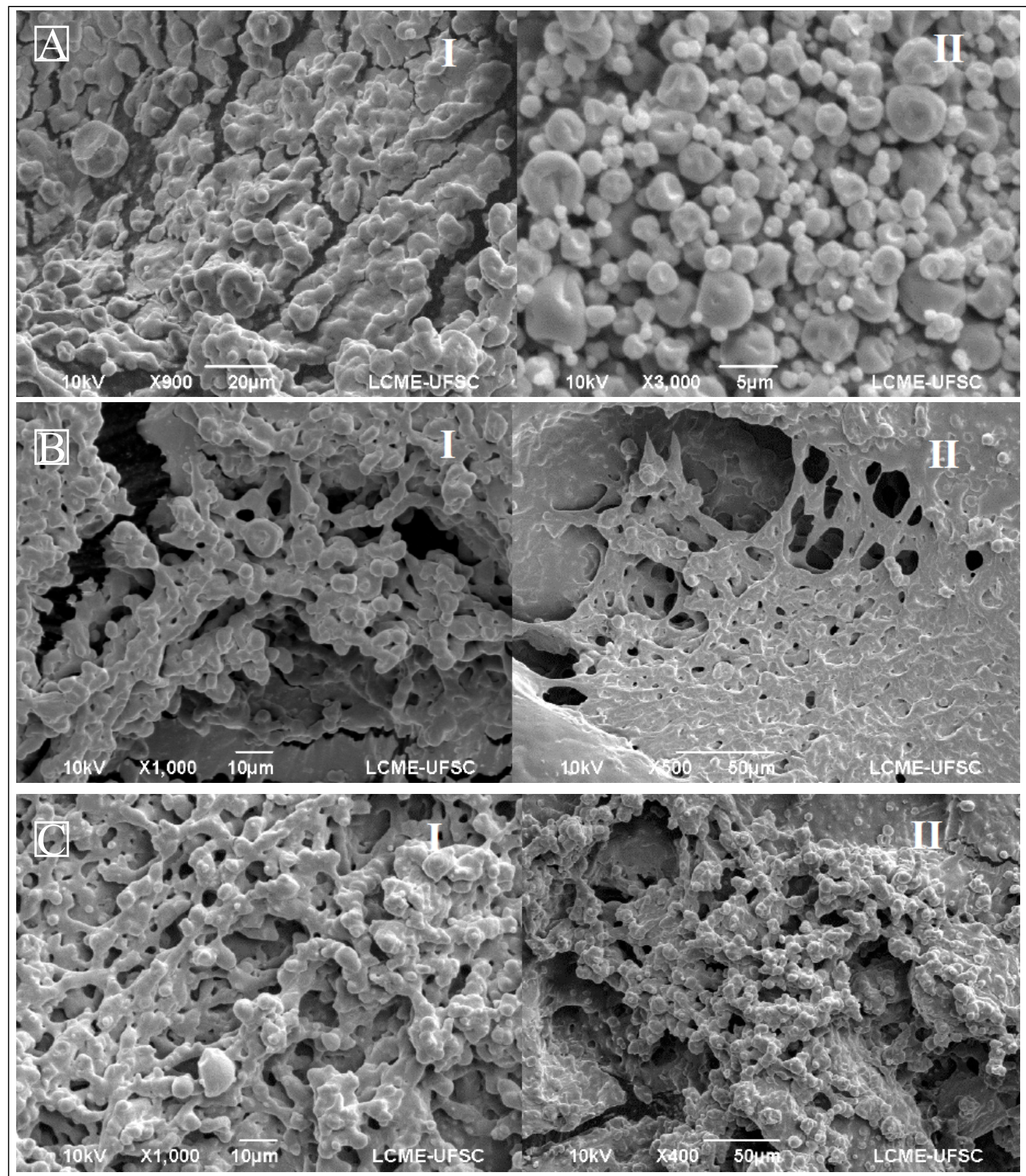

Figure 4 - Scanning electron micrography of maltodextrin and solids of the fermentation wasterwater of P1 - São João do Sul (A): I - DE5 (900X) e II - DE15 (3000X), maltodextrin and solids of the fermentation wasterwater of P2 - Ibirama (B): I - DE5 (1000X) e II DE15 (500X) and maltodextrin and solids of the fermentation wasterwater of P3 - Agronômica (C): I - DE5 (1000X) e II - DE15 (400X). Samples were dried in spray dryer using maltodextrin as support.

\section{ACKNOWLEDGMENTS}

The authors are grateful to the Brazilian governmental agencies Conselho Nacional de Desenvolvimento Científico e
Tecnológico $(\mathrm{CNPq})$ for financial support and Coordenação de Aperfeiçoamento de Pessoal de Nível Superior (CAPES) for scholarships. We would also like to acknowledge the Central Laboratory of Microscopy of the Universidade Federal de Santa Catarina (UFSC) for their support.

Ciência Rural, v.46, n.4, abr, 2016. 


\section{REFERENCES}

AQUINO, A.C.M.S. et al. Validation of HPLC and CE methods for determination of organic acids in sour cassava starch wastewater. Food Chemistry, v.172, p.725-730, 2015 Avalilable from: $<$ http:// dx.doi.org/10.1016/j.foodchem.2014.09.142>. Accessed: Oct. 26, 2015. doi: 10.1016/j.f.oodchem.2014.09.142.

ASCHERI, D.P.R.; VILELA, E.R. Cassava starch appraisal during fermentation and biscuit making processes. Pesquisa Agropecuária Brasileira, v.30, p.269-279, 1995.

AVANCINI, S.R.P. et al. Cassava starch fermentation wastewater: characterization and preliminary toxicological studies. Food and Chemical Toxicology, v.45, p.2273-2278, 2007.

DEMIATE, I.M. et al. Relationship between banking behavior of modified cassava starches and starch chemical structure determined by FTIR spectroscopy. Carbohydrate Polymers, v.42, p.149-158, 2000.

DE VRIES, M.C. et al. Lactobacillus plantarum - survival, functional and potential probiotic properties in the human intestinal tract. International Dairy Journal, v. 16, p.1018-1028, 2006.
MARCON, M.J.A. Expansion properties of sour cassava starch (polvilho azedo): variables related to its practical application in bakery. Starch/ Starke, v.61, p.716-726, 2009.

MARCON, M.J.A. et al. The effect of rapid fermentation of cassava starch sour microstructure. Journal of Food Process Engineering, v.29, p.362-372, 2006

MESTRES, C. et al. Comparison of the expansion ability of fermented maize flour and cassava starch during baking. Journal of the Science of Food and Agriculture, v.80, p.665-672, 2000.

MESTRES, C.; ROUAU, X. Influence of natural fermentation and drying conditions on physicochemical characteristics of cassava starch. Journal of the Science of Food and Agriculture, v. 74, p.147-155, 1997.

MORLON-GUYOT, J. et al. Lactobacillus manihotvorans sp. Nov., a new starch-hydrolyzing lactic acid bacterium isolated during cassava sour starch fermentation. International Journal of Systematic Bacteriology, v.48, n.4, p.1101-1109, 1998.

PLATA-OVIEDO, M.; CAMARGO, C.R.O. Determinação de propriedades físico-químicas e funcionais de duas féculas fermentadas de mandioca (polvilho azedo). Ciência e Tecnologia de Alimentos, v.15, p.59-65, 1995. 